\title{
Diversity and of tree species in tropical forests of Northcentral Eastern Ghats, India
}

\author{
D. PREMAVANI, M. TARAKESWARA NAIDU, O. ANIEL KUMAR, M. VENKAIAH \\ Department of Botany, College of Science and Technology, Andhra University, Visakhapatnam-530003, India. "email: tarakeswaranaidu@ gmail.com
}

Manuscript received: 18 September 2016. Revision accepted: 14 June 2017.

\begin{abstract}
Premavani D, Naidu MT, Kumar OA, Venkaiah M. 2017. Diversity and distribution of tree species in tropical forests of Northcentral Eastern Ghats, India. Asian J For 1: 27-32. Tropical forests are among the most biodiversity rich ecosystems in the world, yet they are understudied. The diversity and stand structure of tree species were studied in three 1-ha sites of tropical deciduous forests in the northcentral Eastern Ghats of India. The phytosociological data from forest sites were analyzed quantitatively to determine the species diversity, richness, basal area and stand density. A total of 1,507 individuals of 104 plant taxa, pertaining to 82 genera under 41 families were enumerated at $\geq 15 \mathrm{~cm}$ gbh (girth at breast height) using belt transects $(5 \mathrm{~m} \times 1000 \mathrm{~m})$. Tree stand density varied from 371 660 individuals per ha while average basal area ranged from $14.54-46.51 \mathrm{~m}^{2} \mathrm{ha}^{-1}$. Shannon-Weiner Index $\left(\mathrm{H}^{\prime}\right)$ ranged from $0.97-0.98$, evenness index ranged from 0.70-0.79 and Margalef richness index ranged from $10.54-10.82$. The most dominant families were Rubiaceae, Euphorbiaceae, Fabaceae, Moraceae, and Verbenaceae. Our results suggest further development of forest management and biodiversity conservation in Eastern Ghats region.
\end{abstract}

Keywords: Diversity, species richness, stand structure, conservation, tropical forests, Eastern Ghats

\section{INTRODUCTION}

Tropical forests are the most species-diverse terrestrial ecosystems on the planet which comprise many endemic species (Sathish et al. 2013). Tropical forests cover only $7 \%$ of the earth's land surface, but harbor more than half of the world's species (Wilson 1988). They provide many ecosystem services, such as carbon sequestration, storing water, preventing soil erosion, and habitat for plants and animals (Anbarashan and Parthasarathy 2013).

In recent years, tropical forests are under great anthropogenic pressures and require management intervention to maintain the overall biodiversity, productivity and sustainability (Dash et al. 2009; Naidu and Kumar 2015). The first step toward the conservation and sustainable management of tropical forests is the availability of data on plant species diversity and the forest community structure. This information is important to serve as the baseline information for monitoring the changes that occurred in a tropical forest, especially because of the impacts of human activities.

Quantitative inventories in tropical forests have been concentrated on tree species than the other life forms since tree species diversity is an important part of an ecosystem (Mani and Parthasarathy 2006; Reddy et al. 2011). Trees form the major structural and functional basis of tropical forest ecosystems and can serve as robust indicators of changes and stresses at the landscape scale (Sahu et al 2012a). The composition and structure of tree vegetation in tropical regions over small geographic scales often have been correlated with changes in topography and soil characteristics (Svenning 1999; Webb and Peart 2000).
Quantitative plant diversity inventories of Indian tropical forests are available from various forests of Eastern Ghats (Kadavul and Parthasarathy 1999a, b; Jayakumar et al. 2002; Natarajan et al. 2004; Reddy et al. 2008; Reddy et al. 2011; Sahu et al. 2012a, b; Premavani et al. 2014). Nonetheless, these kinds of studies are scarce in Andhra Pradesh, which covers a major part of the Eastern Ghats. In view of these conditions, we evaluated the diversity and distribution of tree species in a section of north-central Eastern Ghats, as part of East Godavari District in Andhra Pradesh, aiming to provide fundamental data for appropriate management strategies which will help to improve the ecosystem conservation status.

\section{MATERIALS AND METHODS}

\section{Study area}

The present study was carried out in three forest stands located in East Godavari District, Andhra Pradesh, India. The stands were located $245 \mathrm{~km}$ away from south-west direction of Visakhapatnam. They include Maredumilli (MM: $\left.17^{\circ} 35^{\prime} 18.66^{\prime \prime} \mathrm{N} \quad 81^{\circ} 43^{\prime} 18.66^{\prime \prime} \mathrm{E}\right), \quad$ Rajavommangi (RV: $\left.17^{\circ} 33^{\prime} 35.61^{\prime \prime} \mathrm{N} 82^{\circ} 13^{\prime} 50.44^{\prime \prime} \mathrm{E}\right)$ and Rayapalli (RP: $17^{\circ} 34^{\prime} 15.53^{\prime \prime} \mathrm{N} 82^{\circ} 01^{\prime} 08.42^{\prime \prime} \mathrm{E}$ ) (Figure 1). These forests are classified as Southern moist deciduous and dry deciduous forests (Champion and Seth 1968). The hill range consists mainly of charnokites and kondalites and varied crystalline metamorphic rocks (Subrahmanyam 1982). Soil of the study sites is black, loamy and lateritic. Lateritic soils are abundant in the deciduous forests of the area (Naidu et al. 2014). 


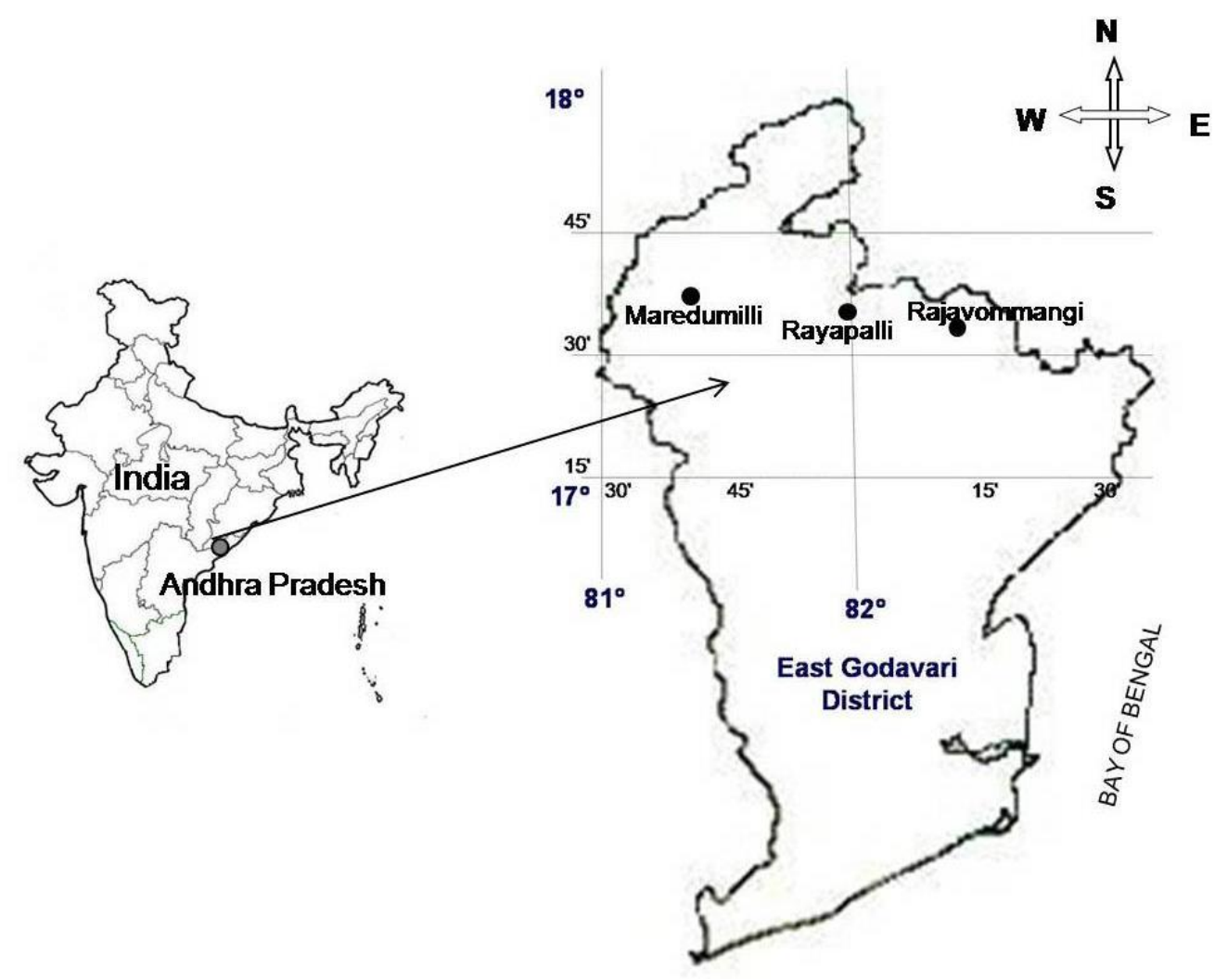

Figure 1. Map showing three study sites in East Godavari District of Andhra Pradesh, India. Note: MM = Maredumilli, RP = Rayapalli, $\mathrm{RV}=$ Rajavommangi

The annual precipitation is $1300 \mathrm{~mm}$ and the temperature rises from $28^{0}$ to $46^{\circ} \mathrm{C}$ in the summer while in the winter it ranges from $13^{0}$ to $27^{\circ} \mathrm{C}$ (Public Works Department/PWD data). The were anthropogenic activities noted such as intentional forest fire, timber cutting, lopping, grazing, and fuelwood and medicinal plant collection. Invasion of exotic species was also observed.

\section{Sampling methods}

The study was carried out during 2009-2011 as part of a national-level project. Two belt transects with size of $5 \times$ $1,000 \mathrm{~m}$ were established. Depending on the shape of the forest stand, these transects were sub-divided into five lines with size $5 \times 200 \mathrm{~m}$ and care was taken to cover landscape heterogeneity and was given by their locality name which was used for further analytical use. All individual trees covered in the quadrats were measured at girth at breast height $(\mathrm{GBH}) \geq 15 \mathrm{~cm}$. Voucher specimens were collected, processed and identified by following Gamble and Fischer (1915-1935) and Rao et al. (1999) and stored in the Botany Department Herbarium (BDH), Department of Botany, Andhra University, Visakhapatnam, for reference.

\section{Data analysis}

Vegetation data were quantitatively analyzed for basal area, relative density (RD), frequency (RF) and dominance (RDom). The Importance Value Index (IVI) of tree species was determined (Curtis and McIntosh 1950). The collected data were also used to compute community indices, namely Species diversity $\left(\mathrm{H}^{\prime}\right)$ which was calculated using the
Shannon-Weiner Index (Shannon and Weiner 1963) as follow:

$$
\mathrm{H}^{\prime}=-\Sigma(\mathrm{Pi}) / \mathrm{In}(\mathrm{Pi}),
$$

Where, $\mathrm{Pi}=\mathrm{ni} / \mathrm{N}, \mathrm{ni}=$ number of all individuals of one species, $\mathrm{N}=$ he total number of individuals of all species, and $\mathrm{In}=$ Logarithm.

Species dominance (Cd) was calculated following GiniSimpson (Simpson 1949) as follow:

$$
\mathrm{Cd}=\Sigma(\mathrm{ni} / \mathrm{N})^{2}
$$

Where, ni and $\mathrm{N}$ are the same as those of ShannonWeiner index. Evenness refers to the degree of relative dominance of each species in that area. It was calculated according to Pielou (1966) as:

\section{Evenness $(\mathrm{e})=\mathrm{H}^{\prime} / \log \mathrm{S}$}

Where, $\mathrm{H}^{\prime}=$ Shannon index, $\mathrm{S}=$ number of species. Species richness was determined by Margalef index (Margalef 1968) as:

$$
\mathrm{d}=\mathrm{S}_{1} / \log \mathrm{N}
$$

Where, $\mathrm{S}$ is the number of species and $\mathrm{N}$ is the number of individuals. 


\section{RESULTS AND DISCUSSION}

\section{Species richness and diversity}

A total of 1,507 individual trees with $\mathrm{gbh} \geq 15 \mathrm{~cm}$ were recorded, consisting of 104 species of 82 genera and 41 families. Of these, 71 species of 61 genera and 33 families occurred in MM, 66 species of 60 genera and 33 families occurred in RV and 65 species of 56 genera and 30 families occurred in RP sites. Stem density varied in the three study sites with 660 in MM, 476 in RV and 371 individuals in RP (Table 1). Rubiaceae was the dominant family with eight species, followed by Euphorbiaceae (6 spp.) and 5 species of each by Anacardiaceae, Apocynaceae, Caesalpiniaceae, Combretaceae, Flacourtiaceae, Mimosaceae, Moraceae, Papilionaceae, Rutaceae, Sterculiaceae and Verbenaceae while three families Annonaceae, Ebenaceae and Sapotaceae were represented by three species each, eight families had two species each and 16 families were represented by only single species. The diversity values 3.9, 3.86, and 3.94 for the sites $M M, R V$, and RP, respectively. The Simpson index was 0.97, 0.97, and 0.98, respectively, Evenness index of tree communities at MM, $\mathrm{RV}$, and RP, represented $0.70,0.72$, and 0.79 , respectively. The Margalef richness index was 10.78, 10.54, and 10.82 for the sites MM, RV, and RP, respectively (Table 1).

Table 1. Number of taxa, diversity indices and structural characteristics of 3 1-ha sites in the northcentral Eastern Ghats, India.

\begin{tabular}{llll}
\hline Variable & MM & RV & RP \\
\hline Latitude & $1^{\circ} 35^{\prime} 37.01^{\prime \prime}$ & $17^{\circ} 33^{\prime} 35.61^{\prime \prime}$ & $17^{\circ} 34^{\prime} 15.53^{\prime \prime}$ \\
Longitude & $81^{\circ} 43^{\prime} 18.66^{\prime \prime}$ & $82^{\circ} 13^{\prime} 50.44^{\prime \prime}$ & $81^{\circ} 01^{\prime} 08.42^{\prime \prime}$ \\
Elevation (m) & 654 & 310 & 307 \\
No. of species & 71 & 66 & 65 \\
No. of genera & 61 & 60 & 56 \\
No. of families & 33 & 33 & 30 \\
Density & 660 & 476 & 371 \\
Basal area & $46.51 \mathrm{~m}^{2} \mathrm{ha}^{-1}$ & $27.47 \mathrm{~m}^{2} \mathrm{ha}^{-1}$ & $14.54 \mathrm{~m}^{2} \mathrm{ha}^{-1}$ \\
Shannon_H & 3.9 & 3.86 & 3.94 \\
Simpson_1-D & 0.97 & 0.97 & 0.98 \\
Evenness_e & 0.70 & 0.72 & 0.79 \\
Margalef & 10.78 & 10.54 & 10.82 \\
\hline
\end{tabular}

\section{Density and basal cover}

The average tree density was 502 individuals ha ${ }^{-1}$ with a range of 371 (Site RP) to 660 individuals $\mathrm{ha}^{-1}$ (MM). Site wise tree species densities were shown as Xylia xylocarpa (36 individuals) followed by Terminalia alata (29 individuals) and Lannea coromandelica (27 individuals) in MM; Cleistanthus collinus (36 individuals), Anogeissus latifolia (32 individuals) and Xylia xylocarpa (27 individuals) in RV; Chloroxylon swietenia (20 individuals), Lannea coromandelica (19 individuals) and Dalbergia paniculata (18 individuals) in RP. The sum of total tree basal area of three sites was $88.52 \mathrm{~m}^{2} \mathrm{ha}^{-1}$ with a range from $14.54 \mathrm{~m}^{2} \mathrm{ha}^{-1}$ (RP) to $46.51 \mathrm{~m}^{2} \mathrm{ha}^{-1}$ (MM).

A comparison was made to see the relative distribution of the total number of individuals and their basal area in each diameter class. The girth $(\mathrm{GBH})$ class-wise tree density followed to girth class intervals were found more for 31-60 $\mathrm{cm}$ and $61-90 \mathrm{~cm}$. In most of the individuals with $52.7 \%$ fall in 31 to $90 \mathrm{gbh}$. The basal area of these classes showed 2.44 and $8.81 \mathrm{~m}^{2} \mathrm{ha}^{-1}$. The highest basal area contributed in $>120 \mathrm{~cm}$ girth class about $31.08 \mathrm{~m}^{2} \mathrm{ha}^{-1}$ (Figure 2.A). In Site RV, girth classes decreased from the smallest to largest trees in context to their stem density except for $<30$ girth class. The girth class $61-90 \mathrm{~cm}$ contributed $26 \%$ of stem density. The distribution of basal area in different girth intervals i.e more than $120 \mathrm{~cm}$ and 91-120 cm contributed about $15.01 \mathrm{~m}^{2} \mathrm{ha}^{-1}$ and $7.05 \mathrm{~m}^{2} \mathrm{ha}^{-1}$, respectively (Figure 2.B). In site RV, stem density decreased consistently with increase in girth class of tree species beyond 31-60 girth class. The distribution of basal area across different girth intervals i.e $>120 \mathrm{~cm}$ and 91-120 $\mathrm{cm}$ contributed $6.21 \mathrm{~m}^{2} \mathrm{ha}^{-1}$ and $3.74 \mathrm{~m}^{2} \mathrm{ha}^{-1}$ respectively (Figure 2.C).

The average tree height was $18.2 \mathrm{~m}$ with ranges from 2 to $21 \mathrm{~m}$. Tree height distribution intervals showed that most of trees in the study area were between 5 and $15 \mathrm{~m}$ in height (Figure 3). This pattern is common for all three sites. The forests in the study sites can be considered for having two defined strata. The first is between 5 and $10 \mathrm{~m}$ which comprises the majority of individuals. The second stratum consists of individuals with 11-15 m high canopy. Very few species reached heights greater than $15 \mathrm{~m}$.

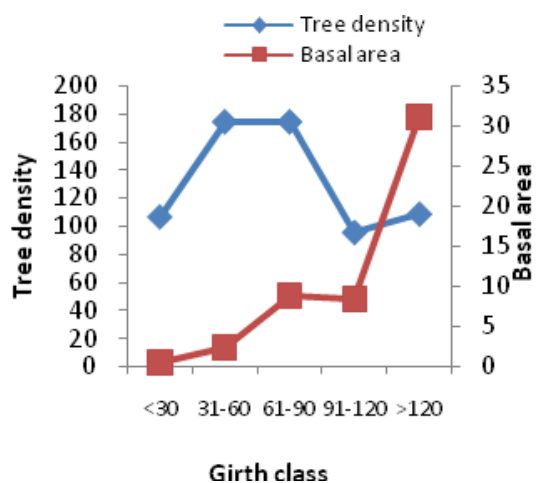

A

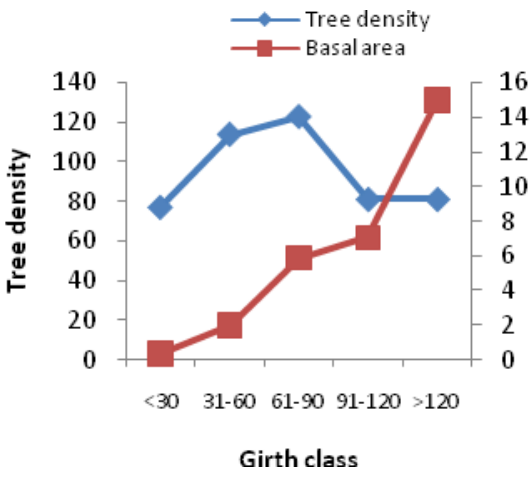

B

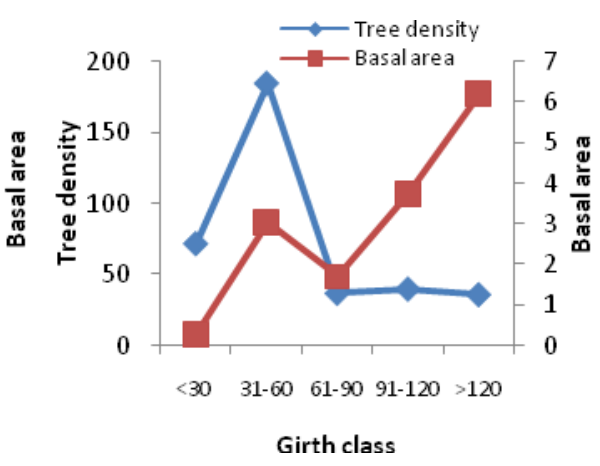

C

Figure 2.A-C. Contribution of tree species, stands density and basal area based on girth class distribution in northcentral Eastern Ghats, India 


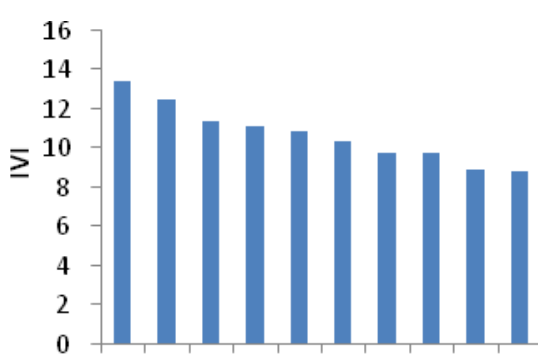

PS TA XX GP CA AL GA HC DP LC

Species

A

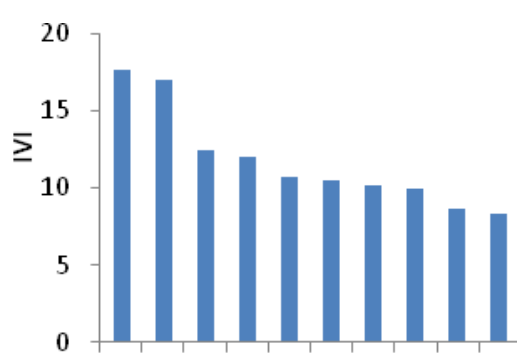

AL XX SC CC LC TA TI GP HC CS Species

B

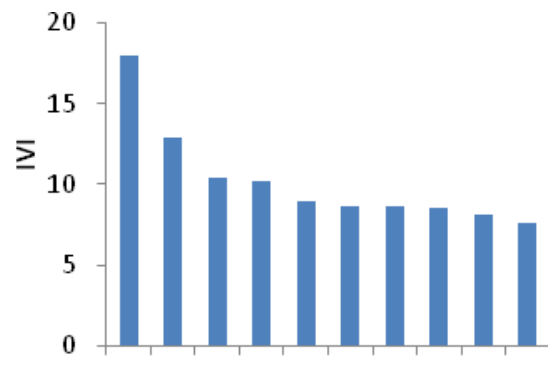

DP LC AL XX MP TA TI AS CS BC

Species

C

Figure 4.A-C. Top ten IVI of tree species in northcentral Eastern Ghats. Abbreviations used $(\mathrm{a}-\mathrm{c})$. PS $=$ Protium serratum; TA $=$ Terminalia alata $; \mathrm{XX}=$ Xylia xylocarpa $; \mathrm{GP}=$ Garuga pinnata $; \mathrm{CA}=$ Careya arborea $;$ AS $=$ Alangium salvifolium $; \mathrm{GA}=$ Gmelina asiatica $; \mathrm{HC}=$ Haldinia cordifolia $; \mathrm{DP}=$ Dalbergia paniculata $; \mathrm{LC}=$ Lannea coromandelica $; \mathrm{SC}=$ Syzygium cumini $;$ CC = Cleistanthus collinus $; \mathrm{TI}=$ Tamarindus indica $; \mathrm{CS}=$ Chlooxylon swietenia $;$ Mitragyna parvifolia $; \mathrm{AL}=$ Anogeissus latifolia .

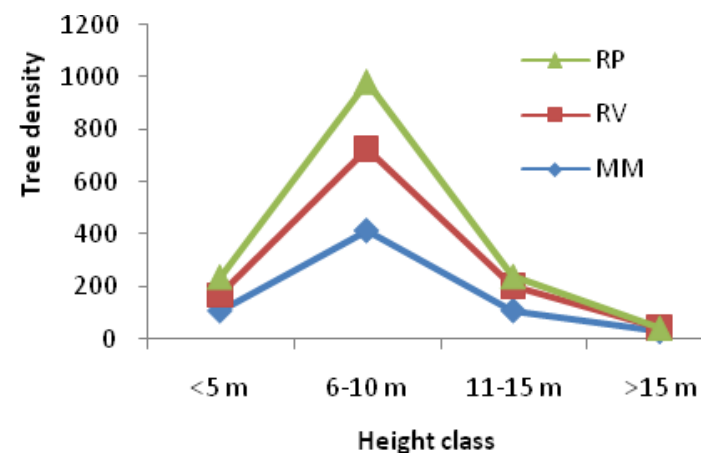

Figure 3. Distribution of individuals per height classes in northcentral Eastern Ghats, India

\section{Important Value Index (IVI)}

Top ten species accounted for $36 \%$ of IVI in MM with Protium serratum as the most dominant species with IVI of 13.5\%. The co-dominant species were Terminalia alata, Xylia xylocarpa, Garuga pinnata, Careya arborea and Anogeissus latifolia (Figure 4.A). In RV, top ten species accounted for 39\% with Anogeissus latifolia as the most dominant species with IVI of $17.67 \%$. The co-dominant species included X. xylocarpa, Syzygium cumini, Cleistanthus collinus, Lannea coromandelica, Terminalia alata and Tamarindus indica (Figure 4.B). In RP, top ten species accounted for $34 \%$, and Dalbergia paniculata was the most dominant species with IVI $17.89 \%$. The codominant species were L. coromandelica, A. latifolia, X. xylocarpa and Mitragyna parviflora (Figure 4.C).

\section{Discussion}

The present study can be compared with a large number of similar forest sites studied in India and elsewhere in the tropics. Tree species richness varied in different stands with total of 104 species of 41 families were recorded from $3 \mathrm{ha}^{-1}$ sites, resulting in species richness ranging from 65$71 \mathrm{ha}^{-1}$ with mean value of $67 \mathrm{ha}^{-1}$ recorded. The mean value of 67 species $\mathrm{ha}^{-1}$ recorded in the present study is higher than that of 31 species ha-1 in dry deciduous forests in western India (Kumar et al. 2010), 9 to 41 species ha $^{-1}$ in Bannerghatta National Park (Gopalakrishna et al. 2015), 32 to 48 species ha $^{-1}$ in natural forests of Barak valley (Nandy and Das 2013) and 64 species ha ${ }^{-1}$ in tropical dry deciduous forests of Eastern Ghats, Southern Andhra Pradesh (Reddy et al. 2008). Species number per ha found in the present study is smaller when compared to results of lowland moist deciduous forests in northeast India which have 105 species $\mathrm{ha}^{-1}$ (Majumdar et al. 2012), 150 species ha-1 in Indonesia (Whitemore 1990), 223 and 214 species ha-1 in Malaysia (Proctor et al. 1983), 223 species ha ${ }^{-1}$ (Parthasarathy and Sethi 1997). The species richness ranged between 65 and 71 per hectare is well within the range reported for tropical forests in Eastern Ghats, i.e. from low value of 22-29 species $\mathrm{ha}^{-1}$ in Niyamgiri hill range of Eastern Ghats (Sahu et al. 2012b) to a high value of 52-110 species $\mathrm{ha}^{-1}$ in Eastern Ghats of northern Andhra Pradesh.

Rubiaceae, Euphorbiaceae, and Papilionaceae were the dominant families in the present study area. There are similar dominant families to be recorded from Eastern Ghats of northern Andhra Pradesh (Reddy et al. 2011), Shervarayan hills (Kadavul and Parthasarathy 1999a), and Warangal region along Godavari valley (Raju et al. 2014). Leguminosae is the dominant family in many Indian deciduous forests, whereas Lauraceae, Meliaceae, Combretaceae, Rubiaceae, Euphorbiaceae and Moraceae, etc. are dominant elsewhere in other areas of India (Sukumar et al. 1992; Shankar 2001). But in tropics, Fabaceae is the most speciose family in Neotropical deciduous forests (Gentry 1995; Martin et al. 1997; Steege et al. 2000). For instance, Protium serratum and Terminalia alata were dominant in MM; Anogeissus latifolia and X. xylocarpa in RV and Dalbergia paniculata and Lannea coromandelica in RP. Reddy et al. (2011) reported Xylia xylocarpa and Pterocarpus marsupium were dominant species in Eastern Ghats of northern Andhra Pradesh; Albizia amara and Euphorbia antiquorum were dominant species in tropical forests of southern Eastern Ghats (Pragasan and Parthasarathy 2010); Microtropis 
discolor and Camella caudata were the dominant trees in Jaintia hills of north east India (Upadhaya et al. 2003).

A total of 1,507 individual trees with the average stand density of 504 individuals ha $^{-1}$ in the present study exists well within the range of 276-905 individuals ha-1 reported for trees $\geq 15 \mathrm{~cm}$ gbh in other tropical forests (Sahu et al. 2012a; Bhadra et al. 2010; Kumar et al. 2010; Sahu et al. 2007) and are close to the value reported by Jha and Singh (1990) for dry tropical forest of Vindhyan region of India. The basal area is an important aspect of studying forest vegetation and structure (Williams-Linera 1990). The mean basal area was $29 \mathrm{~m}^{2} \mathrm{ha}^{-1}$ for the study sites, ranging from 14.54 to $46.51 \mathrm{~m}^{2} \mathrm{ha}^{-1}$. It is close to that of other tropical forests, such as dry evergreen $\left(32.8 \mathrm{~m}^{2} \mathrm{ha}^{-1}\right)$ forests of Puthupet, south India (Parthasarathy and Sethi 1997), tropical forests of Eastern Ghats of northern Andhra Pradesh (Reddy et al. 2011), fan-palm dominated forests of east coast (25.3-48.6 $\mathrm{m}^{2} \mathrm{ha}^{-1}$ ) in Malaysia (Nizam et al. 2013) but when compared to tropical rain forest in Amazonia (Campbell et al. 1992) lower in value $\left(78 \mathrm{~m}^{2} \mathrm{ha}\right.$ $\left.{ }^{1}\right)$.

With respect to girth class wise distribution, tree density decreased with increasing tree size classes, except in lower size class. This agrees with the studies from Malayagiri and Niyamgiri hill ranges of Eastern Ghats (Sahu et al. 2012a, 2012b). The mean tree height was $18.2 \mathrm{~m}$, ranging from 2 to $21 \mathrm{~m}$. The distribution of tree height class showed that individuals were between 5 and $15 \mathrm{~m}$, this is in conformity with the findings for the Malayagiri hill ranges of Eastern Ghats (Sahu et al. 2012a) and dry tropical forests of Peru (Palomino and Alvarez 2005).

Species diversity depends upon adaptation of species and increases with stability of community. The Shannon Weiner $\left(\mathrm{H}^{\prime}\right)$ index for all three sites varied from 3.86 to 3.94 , which falls within the range of $0.67-4.86$ reported by earlier works in tropical forests (Sundarapandian et al. 2000; Dash et al. 2009; Kumar et al. 2010; Sahu et al. 2012a). These values indicate that the present tropical deciduous forest is in a species diverse system. The concentration of dominance (Simpson's index) in the present study is within the reported range 0.21-1.0 for tropical forests by several studies (Kumar et al. 2010; Visalakshi 1995; Sahu et al. 2012c). The evenness index values fall within the range between 0.64-1.34 in other forests (Lalfakwma et al. 2009; Sahu et al. 2012a). The Margalef richness index is also within the range of 4.5423.41 for other tropical forests (Mishra et al. 2005; Kumar et al. 2010).

In conclusion, forests are a rich repository of India's biodiversity but widespread habitat destruction is threatening its status. Plant diversity in tropical forests was mostly associated with forest structure and species composition. Quantitative inventory of tree species diversity revealed a considerable variation in the composition of dominant species and stood density between forest areas and calculations of IVI which have helped in understanding the ecological significance of species, from different communities. However, the present study clearly shows the fact that the tree diversity in tropical forests of Eastern Ghats varies in species richness and structure among study sites, mainly due to variation in physical heterogeneity and habitat disturbance. Our results highlight the necessity of preparing a comprehensive management plan to conserve the ecosystem of the northcentral Eastern Ghats for its rich biodiversity. The present study further helps policymakers to formulate policies to conserve the natural forest ecosystems and as well for the proper utilization of natural resources.

\section{REFERENCES}

Anbarashan M, Parthasarathy N. 2013. Tree diversity of tropical dry evergreen forests dominated by single or mixed species on the Coromandel Coast of India. Trop Ecol 54 (2):179-190.

Bhadra AK, Dhal NK, Rout NC, Reddy VR. 2010. Phytosociology of the tree community of Gandhamaran hill ranges. Indian For 136 (5): 610620 .

Campbell DG, Stone JL, Rosas AJr. 1992. A comparison of the phytosociology and dynamics of three flood plain (Vazae) forests of known ages, Rio, Jurua, Western Brazilian Amazon. Bot J Linn Soc 108: 213-237. DOI: 10.1111/j.1095-8339.1992.tb00240.x

Champion HG, Seth SK. 1968. A Revised Survey of the Forest Types of India. Government of India Publications, New Delhi, India.

Chittibabu CV, Parthasarathy N. 2000. Attenuated tree species diversity in human-impacted tropical evergreen forest at Varagalair, Anamalais, Western Ghats, India. Biodiver Conserv 9: 1493-1519.

Curtis JT, McIntosh RP. 1950. The interrelations of certain analytic and synthetic phytosociological characters. Ecology 31: 434-455. DOI: $10.2307 / 1931497$

Dash PK, Mohapatra PP, Rao YG. 2009. Diversity and distribution pattern of tree species in Niyamgiri hill ranges, Orissa, India. Indian For 135 (7): 927-942.

Gamble JS, Fischer CEC. 1915-1935. Flora of the Presidency of Madras, (3 vols.). (Rep.ed. 1957). Adlard and Son Ltd., London.

Gentry AH. 1995. Diversity and floristic composition of Neotropical dry forests. In: Bullock SH, Mooney HA, Mdina E. (eds). Seasonally dry tropical forests. Cambridge University Press, Cambridge.

Gopalakrishna SP, Kaonga ML, Somashekar RK, Suresh HS and Suresh R. 2015. Tree diversity in the tropical dry forest of Bannerghatta National Park in Eastern Ghats, Southern India. Eur J Ecol 1 (2): 1227. DOI: $10.1515 /$ eje-2015-0013

Jayakumar S, Arockiasamy DI, Britto SJ. 2002. Conserving forests in the Eastern Ghats through remote sensing and GIS: A case study in Kolli hills. Curr Sci 82: 1259-1267.

Jha CS, Singh JS. 1990. Composition and dynamics of dry tropical forest in relation to soil texture. Journal of Vege Sci 1: 609-614. DOI: $10.2307 / 3235566$

Kadavul K, Parthasarathy N. 1999b. Structure and composition of woody species in tropical semi-evergreen forest of Kalrayan hills, Eastern Ghats, India. Trop Ecol 40: 247-260.

Kumar JIN, Kumar RN, Bhoi RK and Sajish PR. 2010. Tree species diversity and soil nutrient status in three sites of tropical dry deciduous forest of western India. Trop Ecol51 (2): 273-279.

Lalfakwma, Sahoo UK, Roy S, Vanlalhriatpuia K and Vavalalhluna PC. 2009. Community composition and tree population structure in undisturbed and disturbed tropical semi-evergreen forest stands of North-East India. Appl Ecol Envi Res 7: 303-318.

Majumdar K, Shankar U, Dutta BK. 2012. Tree species diversity and stand structure along major community types in lowland primary and secondary moist deciduous forests in Tripura, Northeast India. JFore Res23 (4): 553-568. DOI: 10.1007/s11676-012-0295-8

Mani S, Parthasarathy N. 2006. Tree diversity and stand structure in inland and coastal tropical dry evergreen forests of peninsular India. Curr Sci 90: 1238-1246.

Margalef R. 1968. Perspectives in Ecological Theory. University of Chicago Press, Chicago. pp: 111.

Martin ME, Aber JD. 1997. High spectral resolution remote sensing of forest canopy lignin, nitrogen and ecosystem processes. Ecol Appli 7: 431-443. DOI: 10.1890/10510761(1997)007[0431:HSRRSO]2.0.CO;2 
Meng J, Lu Y, Lei X, Liu G. 2011. Structure and floristics of tropical forests and their implications for restoration of degraded forests of China's Hainan Island. Trop Ecol52 (2): 177-191.

Mishra BP, Tripati OP, Laloo RC. 2005. Community characteristics of a climax subtropical humid forest of Meghalaya and population structure of ten important tree species. Trop Ecol 46 (2): 241-251.

Naidu MT, Kumar OA, Venkaiah M. 2014. Taxonomic diversity of lianas in tropical forests of northern Eastern Ghats of Andhra Pradesh, India. Not Sci Biol 6 (1): 59-65. DOI: 10.15835/nsb.6.1.9193

Naidu MT, Kumar OA. 2015. Tree species diversity in the Eastern Ghats of northern Andhra Pradesh. J Thre Taxa 7 (8): 7443-7459. DOI: 10.11609/JoTT.o3764.7443-59

Nandy S and Das AK. 2013. Comparing tree diversity and population structure between a traditional agroforestry system and natural forest of Barak Valley, Northeast India. Intl J Biod Scie Eco Syst Man 9: 104-113. DOI: 10.1080/21513732.2012.748691

Natarajan D, Britto SJ, Balagaru B, Nagamurugan N, Soosairaj S and Arockiasamy DI. 2004. Identification of Conservation priority sites using remote sensing and GIS - A case study from Chitteri hills, Eastern Ghats, Tamil Nadu. Curr Sci 86: 1316-1323.

Nizam MS, Jeffri AR, Latiff A. 2013. Structure of tree communities and their association with soil properties in two fan-palm dominated forests of east coast Peninsular Malaysia. Trop Ecol 54: 213-226.

Palomino LR, Alvarez SIP. 2005. Tree community patterns in seasonally dry tropical forests in the Cerros de Amotape Cordillera, Tumbes, Peru. For Ecol Manag 209: 261-272. DOI: 10.1016/j.foreco.2005.02.003

Parthasarathy N, Sethi P. 1997. Tree and liana species diversity and population structure in a tropical dry evergreen forest in south India. Trop Ecol 38: 19-30.

Pielou EC. 1966. The measurement of diversity in different types of biological collections. J Theo Biol 13: 131-144. DOI: 10.1016/00225193(66)90013-0

Pragasan LA, Parthasarathy N. 2010. Landscape-level tree diversity assessment in tropical forests of southern Eastern Ghats, India. Flora 205: 728-737. DOI: 10.1016/j.flora.2010.04.011

Premavani D, Naidu MT, Venkaiah M. 2014. Tree species diversity and population structure in the tropical forests of north-central Eastern Ghats, India. Not Sci Biol 6 (4): 448-453. DOI: DOI: 10.15835/nsb.6.4.9382

Proctor J, Anderson JM, Chai P, Vallack HW. 1983. Ecological studies in four contrasting lowland rain forests in Gunug Mulu National Park Sarawak. I-Forest environment structure and floristics. J Ecol 71: 237-360. DOI: $10.2307 / 2259975$

Rao RS, Sudhakar S, Venkanna P. 1999. Flora of East Godavari District, Andhra Pradesh, India. INTACH, A.P. State Chapter, Hyderabad.

Raju VS, Krishna PG, Suthari S. 2014. Environmental assessment of climate of a habitat through floristic life-form spectra, a case study of Warangal north forest division, Telangana, India. J Nat Sci 2 (1): 77 93

Reddy CS, Babar S, Amarnath G, Pattanaik C. 2011. Structure and floristic composition of tree stand in tropical forest in the Eastern Ghats of northern Andhra Pradesh, India. J For Res 22 (4): 491-500. DOI: $10.1007 / \mathrm{s} 11676-011-0193-5$

Reddy CS, Shilpa B, Giriraj A, Reddy KN and Rao KT. 2008. Structure and floristic composition of tree diversity in tropical dry deciduous forest of Eastern Ghats, Southern Andhra Pradesh, India. Asian J Sci Res 1 (1): 57-64. DOI: 10.3923/ajsr.2008.57.64
Sahu SC, Dhal NK, Dutt B. 2012c. Environmental implications of biological spectrum vis-à-vis tree species diversity in two protected forests (PFs) of Gandhamaran hill ranges, Eastern Ghats, India. Environmentalist 32: 420-432. DOI: 10.1007/s10669-012-9405-6

Sahu SC, Dhal NK, Mohanty RC. 2012a. Tree species diversity, distribution and population structure in a tropical dry deciduous forest of Malayagiri hill ranges, Eastern Ghats, India. Trop Ecol 53 (2): 163 168.

Sahu SC, Dhal NK, Reddy CS, Pattanaik C and Brahmam M. 2007. Phytosociological study of tropical dry deciduous forest of Boudh district, Orissa, India. Res J For 1: 66-72.

Sahu, SC, Dhal NK, Lal B, Mohanty RC. 2012b. Differences in tree species diversity and soil nutrient status in a tropical sacred forest ecosystem on Niyamgiri hill range, Eastern Ghats, India. J Mou Sci 9: 492-500. DOI: 10.1007/s11629-012-2302-0

Sathish BN, Viswanath S, Kushalappa CG, Jagadish MR and Ganeshaiah KN. 2013. Comparative assessment of floristic structure, diversity and regeneration status of tropical rain forests of Western Ghats of Karnataka, India. J Appl Nat Sci 5 (1): 157-164.

Shankar, U. 2001. A case of high tree diversity in a sal (Shorea robusta)dominated lowland forest of Eastern Himalaya: floristic composition, regeneration and conservation. Curr Sci81: 776-786.

Shannon CE, Weiner W. 1963. The Mathematical Theory of Communication. University of Illinois Press. Urbana, U.S.A.

Simpson EH. 1949. Measurement of diversity. Nature163: 688

Singh JS. 2002. The biodiversity crisis: a multifaceted review. Curr Sci 82: 638-647.

Steege HT, Sabatier D, Castellanos H, Van Andel T, Duivenvoorden J, de Oliviera AA, Ek R, Lilwah R, Maas P and Mori S. 2000. An analysis of the floristic composition and diversity of Amazonian forests including those of the Guiana Shield. J Trop Ecol 16: 801-828. DOI: 10.1017/S0266467400001735

Subrahmanyam VP. 1982. Eastern Ghats region, vegetation and climatic aspects. Proceedings of the seminar on resources, documentation, and environment on the Eastern Ghats. 26pp.

Sukumar R, Dattaraja HS, Suresh HS, John R, Joshi NV. 1992. Long-term monitoring of vegetation in a tropical deciduous forest in Madumalai, southern India. Curr Sci 62: 608-616.

Sundarapandian SM, Swamy PS. 2000. Forest ecosystem structure and composition along an altitudinal gradient in the Western Ghats, South India. J Trop For Sci 12: 104-123.

Svenning JC. 1999. Microhabitat specialization in a species-rich palm community in Amazonian Ecuador. J Ecol 87:55-65.

Upadhaya K, Pandey HN, Law PS, Tripathi RS. 2003. Tree diversity in sacred groves of Jaintia hills in Meghalaya, northeast India. Biodiver Conserv 12: 583-597. DOI: 10.1023/A:1022401012824

Visalaksi N. 1995. Vegetation analysis of two tropical dry evergreen forests in south India. Trop Ecol 36: 117-127.

Webb CO, Peart DR. 2000. Habitat associations of trees and seedlings in a Bornean rain forest. J Ecol 88: 464-478. DOI: 10.1046/j.13652745.2000.00462.x

Whitmore TC. 1990. An introduction to tropical rain forests. Oxford University Press, Oxford.

Williams-Linera G. 1990 Vegetation structure and environmental conditions of forest edges in Panama. J Ecol 78: 356-373. DOI: $10.2307 / 2261117$

Wilson EO. 1988. The current state of biological diversity. In: Wilson EO. (ed.). Biodiversity. The National Academic Press, Washington, DC. 